Tohoku J. Exper. Med., 1963, 81, 267-278

\title{
Results of Surgery in 1988 Surgical Cases of Stomach Cancer*
}

\author{
By \\ Masao Muto,** Susumu Majima, Koichi Yoshida, \\ Katsumi Karube, Teiichi Teshima \\ and Iwao Yamaguchi \\ From the Department of Surgery, Tohoku University \\ School of Medicine, Sendai; Directors: Prof. \\ Emeritus $M$. $M$ u to and Prof. T. $M$ a ki \\ (Received for publication, November 8, 1963)
}

\begin{abstract}
In a total of 1988 cases of stomach cancer surgically treated at the authors' department, the hospital mortality rate was 7.9 per cent with subtotal gastrectomy, 11.7 per cent with proximal gastrectomy, 12.3 per cent with total gastrectomy and 16.9 per cent in non-resection cases. A follow-up study of 1347 gastrectomized cases (93.3 per cent of 1441 survivors of gastrectomy) revealed a 5 year survival rate of 26.8 per cent on an average, 30.8 per cent with subtotal gastrecto$\mathrm{my}$ and 10.4 per cent with proximal or total gastrectomy. The long-term as well as the immediate results of gastrectomy were found to have been much improved in recent years and the 5 year survival rate was as high as 37.9 per cent for those subjected to subtotal gastrectomy during the years 1956 to 1959 .
\end{abstract}

Among the statistics on 1988 cases of stomach cancer treated surgically at the authors' department, those concerning pathologic and clinical aspects were published in the previous communications ${ }^{1,2}$. The present paper is concerned with the immediate and late results of surgery in these patients.

\section{MATERIALS}

The statistics to be presented in this paper are based on 1988 patients of stomach cancer who underwent surgery at the Department of Surgery, Tohoku University School of Medicine, during the 20 year period from April, 1941 to March, 1961.

The types of surgery performed on these patients are shown in Table I. The stomach was resected in 1579 cases, or 79.4 per cent of the 1988 cases. In most instances, the resection was carried out by subtotal gastrectomy. Proximal

武藤完婎, 間島 進, 吉田弘一, 軽部克己, 手島貞一, 山口 籍

* The Third Report of a Statistical Study of 1988 Surgical Cases of Stomach Cancer

** Present address, President, Fukushima Medical College, Fukushima, Japan 
TABLE I. Types of Surgery in 1988 Cases of Stomach Cancer

\begin{tabular}{c|r|c}
\hline Types & No. of cases & Per cent \\
\hline Resection & 1579 & 79.4 \\
Subtotal gastrectomy & 1259 & \\
Proximal gastrectomy & 60 & \\
Total gastrectomy & 260 & \\
Non-resection & 409 & 20.6 \\
Anastomosis & 199 & \\
Simple laparotomy & 210 & \\
\hline Total & 1988 & 100.0
\end{tabular}

TABLE II. Resection of Adjacent Organs Performed in Combination with Gastrectomy

\begin{tabular}{l|r|r|r}
\hline $\begin{array}{r}\text { Types of } \\
\text { gastrectomy } \\
\text { Resected } \\
\text { organs }\end{array}$ & $\begin{array}{c}\text { Subtotal } \\
\text { (1259 cases) }\end{array}$ & $\begin{array}{c}\text { Proximal } \\
\text { (60 cases) }\end{array}$ & $\begin{array}{c}\text { Total } \\
\text { (260 cases) }\end{array}$ \\
\hline Pancreas & 9 & 2 & 9 \\
Spleen & 2 & 10 & 38 \\
Liver & 6 & & 4 \\
Transverse colon & 23 & 1 & 6 \\
Sp.+T.C. & 1 & 11 & 20 \\
Sp.+Pa. & & & 2 \\
Pa.+Li. & & 2 & 1 \\
Pa.+Li.+T.C. & & 26 & 2 \\
Sp.+Pa.+T.C. & 41 & 43.3 & 82 \\
\hline Total & 3.3 & & 31.5 \\
Per cent & & &
\end{tabular}

gastrectomy was indicated only in selected cases of carcinoma of the cardiac region in which the lesion, including extragastric involvement, appeared to be removable by this technique, and total gastrectomy in those with extensive carcinoma that could not be removed by subtotal or proximal gastrectomy.

Of the 1579 cases of stomach resection, 149 received simultaneous resection of an adjacent organ or organs. As shown in Table II, such complicated resection was more frequently combined with proximal or total gastrectomy than with subtotal gastrectomy. In the descending order of frequency, the involved organs were the spleen, pancreas, transverse colon and liver.

Although a stomach resection could be regarded to be curative or radical on some occasions, there were cases of intended palliative gastrectomy in which the stomach was resected for palliation without the attempts to clear advanced extragastric involvement. Inasmuch as there were also a number of cases in which the radicality of stomach resection remained obscure, the authors dared not to make a clear-cut differentiation of the radical vs. palliative gastrectomies which might lead to an erroneous information. 
In a total of 409 cases the lesion was judged to be irresectable. One hundred ninety-nine cases of them received palliative operations which were gastroenterostomy on most occasions and external gastrostomy in a few cases of cardiac obstruction.

\section{RESULTS}

\section{Hospital Mortality}

\section{Mortality rate}

In this paper, hospital mortality refers to the death within one month after operation regardless of the cause of the death. As shown in Table III, the hospital mortality rate was 8.7 per cent for stomach resection and 16.9 per cent in non-resection cases, the over-all rate being 10.4 per cent in this series. That the mortality rate was much higher with anastomosis or simple laparotomy than with stomach resection may reflect the fact that the objectives of the former operations included cases so advanced that did not allow surgical intervention.

TABLE III. Hospital Mortality by Types of Surgery

\begin{tabular}{c|c|c|c}
\hline Types of surgery & $\begin{array}{c}\text { Total no. } \\
\text { of cases }\end{array}$ & $\begin{array}{c}\text { No. of } \\
\text { hospital death }\end{array}$ & Mortality rate \\
\hline Resection & 1579 & 138 & $8.7 \%$ \\
Subtotal gastrectomy & 1259 & 99 & $7.9 \%$ \\
Proximal gastrectomy & 60 & 7 & $11.7 \%$ \\
Total gastrectomy & 260 & 32 & $12.3 \%$ \\
Non-resection & 409 & 69 & $16.9 \%$ \\
Anastomosis & 199 & 37 & $18.6 \%$ \\
Simple laparotomy & 210 & 32 & $15.2 \%$ \\
\hline Total & 1988 & 207 & $10.4 \%$
\end{tabular}

Among the three types of stomach resection, subtotal gastrectomy, which was the simplest in technique and least frequently associated with combined resection of the adjacent organs, gave lower mortality rate (7.9 per cent) than proximal or total gastrectomies did (11.7 per cent and 12.3 per cent, respectively).

2. Recent decrease in hospital mortality

Table IV shows the hospital mortality in this series separately for the first 10 years (from 1941 to 1950 ) and the last 10 years (from 1951 to March, 1961). A significant decrease in hospital mortality was revealed both for the stomach resection and for the non-resection groups; the over-all rate has decreased from 15.2 per cent in the first 10 years to 7.0 per cent in the last 10 years. In stomach resection, including subtotal, proximal and total gastrectomies, the mortality has been reduced from 13.0 per cent to as low as 6.1 per cent. The decrease in hospital mortality was most remarkable with subtotal gastrectomy; the mortality rate 
was only 4.1 per cent in the last 10 years as compared with 12.8 per cent in the former period.

TABLE IV. Hospital Mortality for the First and Last 10-Year-periods*

\begin{tabular}{l|c|c|c}
\hline $\begin{array}{c}\text { Types } \\
\text { of surgery }\end{array}$ & First 10 years & Last 10 years & Total \\
\hline Resection & $13.0(78 / 600)$ & $6.1(60 / 979)$ & $8.7(138 / 1579)$ \\
Subtotal & $12.8(70 / 547)$ & $4.1(29 / 712)$ & $7.9(99 / 1259)$ \\
Proximal or total & $15.1(8 / 53)$ & $11.6(31 / 267)$ & $12.2(39 / 320)$ \\
Non-resection & $20.7(49 / 237)$ & $11.6(20 / 172)$ & $16.0(60 / 409)$ \\
Anastomosis & $19.3(27 / 140)$ & $16.9 /(10 / 59)$ & $18.6(37 / 199)$ \\
Simple laparotomy & $22.7(22 / 97)$ & $8.8(10 / 113)$ & $15.2(32 / 210)$ \\
\hline Total & $15.2(127 / 837)$ & $7.0(80 / 1151)$ & $10.4(207 / 1988)$
\end{tabular}

* In per cent. In parentheses, the denominator indicates the number of operations and the numerator that of hospital deaths.

The Table also indicates a considerable elevation of the resectability rate. In the last 10 years, 979 among 1151 cases (85.1 per cent) were subjected to gastrectomy while in the first 10 years stomach resection was indicated in 600 of the 837 cases ( 71.7 per cent). Thus it should be noted that the recent decrease in hospital mortality has been attained despite the much extended objectives of gastrectomy. This relationship may be more clearly seen in Fig. 1 where the annual trends are shown both for the resectability rate and for the hospital

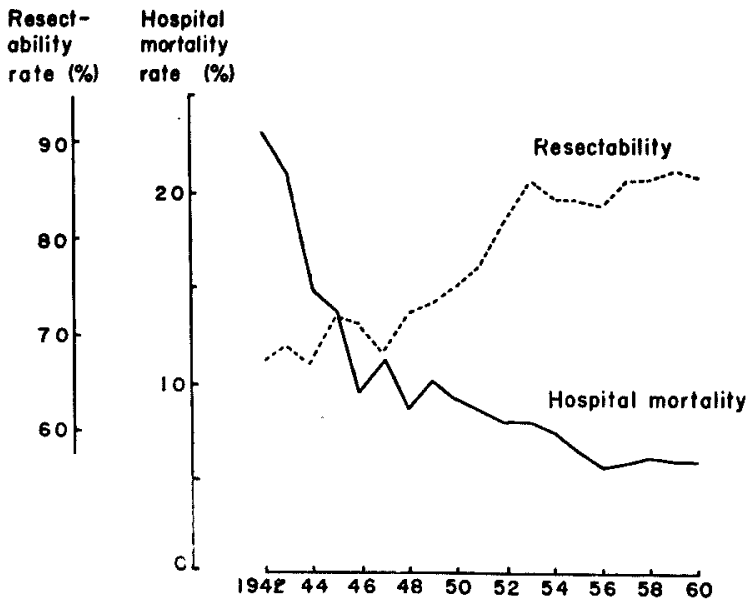

Fig. 1. Annual trends of the resectability rate and the hospital mortality rate of the gastrectomized in the authors' series. The curves were prepared by the moving average method with an interval of three years. 
mortality rate with gastrectomy. Such improvements in resectability rate of stomach cancer as well as in hospital mortality after stomach resection are mainly due to the recent progress in pre-operative and post-operative managements, among which are the development of antibacterial chemotherapy and an advance in fluid therapy. It should be remarked that the first 10 years in this series included the period during and shortly after the Second World War during which surgical practice was forced into the worst condition due to the shortage of surgeons and materials. Recent progress in early diagnosis of stomach cancer may also be a factor contributing to the improvements.

TABle V. Hospital Mortality after Stomach Resection for Carcinoma, Previous Reports

\begin{tabular}{|c|c|c|c|}
\hline Authors & Period & $\begin{array}{l}\text { No. of } \\
\text { resections }\end{array}$ & $\begin{array}{l}\text { Hospital } \\
\text { mortality }\end{array}$ \\
\hline \multirow{3}{*}{ Miyake et $a l . .^{3}$} & 1904-1914 & 177 & $33.1 \%$ \\
\hline & 1914-1919 & 179 & $29.3 \%$ \\
\hline & $\mid 1920-1927$ & 395 & $14.2 \%$ \\
\hline Tomoda and Tomonaga & 1918-1941 & 709 & $21.0 \%$ \\
\hline Obara et al. ${ }^{51}$ & $1946-1950$ & 833 & $2.9 \%$ \\
\hline Nakayama et $a l^{0}$ ) & $1946-1958$ & 1011 & $2.1 \%$ \\
\hline Hoshino? & $1946-1961$ & 1875 & $3.0 \%$ \\
\hline Miwa ${ }^{8}$ & $1947-1961$ & 999 & $6.8 \%$ \\
\hline \multirow[t]{2}{*}{ Berkson et $a l^{8}{ }^{81}$} & $\left\{\begin{array}{l}1907-1937 \\
1938-1949\end{array}\right.$ & 4592 & $16.2 \%$ \\
\hline & (1936-1939 & 67 & $38.8 \%$ \\
\hline \multirow[t]{3}{*}{ Shahon et al. $\left.{ }^{10}\right)$} & $\{1940-1945$ & 247 & $12.1 \%$ \\
\hline & $1946-1949$ & 261 & 8. $8 \%$ \\
\hline & $(1932-1939$ & 140 & 26.496 \\
\hline \multirow[t]{2}{*}{ Marshall and Adamson ${ }^{11)}$} & $\{1940-1949$ & 468 & $10.3 \%$ \\
\hline & $(1950-1954$ & 248 & $6.0 \%$ \\
\hline Rapant12) & $1946-1957$ & 1083 & $13.1 \%$ \\
\hline Holder and Grimsehl ${ }^{133}$ & $1943-1959$ & 639 & $28.3 \%$ \\
\hline & $\{1941-1950$ & 600 & $13.0 \%$ \\
\hline Present series & |1951-1961 & 979 & $6.1 \%$ \\
\hline
\end{tabular}

In Table $\mathrm{V}$ are cited some of hospital mortality rates after stomach resection for carcinoma which appeared in literature. Although the data are not immediately comparable with each other inasmuch as they are associated with different surgical rates, resectability rates and principles of stomach resection, a tendency may be clearly seen toward the recent reduction in hospital mortality.

3. Cause of hospital mortality

Table VI shows the frequency distribution of the cause of hospital mortality in the present series. Deaths after stomach resection and those after other surgeries were tabulated separately and both analyzed for the first 10 years and the last 10 years. Of various causes of deaths, those which stem mainly from technical imperfections are shown in the top four rows and those less related to 
TABLE VI. Cause of Hospital Deaths after Surgery for Stomach Cancer

\begin{tabular}{|c|c|c|c|c|c|c|}
\hline \multirow[t]{2}{*}{$\begin{array}{l}\text { Type and No. } \\
\text { of operations* }\end{array}$} & \multicolumn{2}{|c|}{ Resection } & \multicolumn{2}{|c|}{ Non-resection } & \multicolumn{2}{|c|}{ Total } \\
\hline & $\begin{array}{c}\text { (a) } \\
600\end{array}$ & $\begin{array}{c}\text { (b) } \\
979\end{array}$ & $\begin{array}{c}\text { (a) } \\
237\end{array}$ & $\begin{array}{l}\text { (b) } \\
172\end{array}$ & $\begin{array}{l}\text { (a) } \\
837\end{array}$ & $\begin{array}{c}\text { (b) } \\
1151\end{array}$ \\
\hline Anesthetic death & 1 & 1 & 1 & 1 & 2 & 2 \\
\hline Purulent peritonitis & 21 & 23 & 3 & 1 & 24 & 24 \\
\hline Gastrointestinal bleeding & 3 & 3 & 1 & 1 & 4 & 4 \\
\hline Intestinal obstruction & 1 & 1 & 1 & 3 & 2 & 4 \\
\hline General weakness & 37 & 20 & 36 & 11 & 73 & 31 \\
\hline Pulmonary complications & 12 & 6 & 5 & 2 & 17 & 8 \\
\hline Cerebral vascular accident & 1 & 3 & & & 1 & 3 \\
\hline Miscellaneous & 2 & 3 & 2 & 1 & 4 & 4 \\
\hline Total & 78 & 60 & 49 & 20 & 127 & 80 \\
\hline
\end{tabular}

* (a) refers to the first 10 years from 1941 to 1950 and (b) to the last 10 years thereafter.

errors in surgery in the bottom four. However, the differentiation is only arbitrary as will be discussed below.

Common to both the resection and the non-resection groups, the general weakness including post-operative cardiovascular failure was the most frequent cause of hospital deaths. This seems to be related to the high surgical rate and high resectability rate in this series and may suggest too much access to surgery. Although post-operative pulmonary complications were one of the frequent causes of hospital mortality in the former period, the incidence has decreased much in the last 10 years.

In the resection group, acute purulent peritonitis due to leaking gastrointestinal anastomosis or leaking duodenal stump was the next most common cause of hospital mortality, the rate being 3.5 per cent of the gastrectomized cases (21 of 600 ) in the former 10 years and 2.3 per cent (23 of 979) in the latter period. Although technical imperfections alone are usually called to account in this case, participation of improperly interpreted surgical indications cannot be absolutely excluded on some occasions. In fact, dehiscence of anastomoses or duodenal stumps is known to be likely in patients of malnutrition and gastrectomy on underestimated advanced lesions is not uncommonly forced into imperfect sutures.

Thus the authors believe that the majority of hospital mortalities after surgery for stomach cancer are more or less related to improper surgical indications. In other words, the mortality rate would be much lower when surgical intervention was limited only to selected cases with favorable local as well as general conditions. However, this would also result in a decrease in the resectability rate; a smaller number of patients would be given opportunities for surgical treatment which is the only sure way in controlling this fatal disease. This is a difficult problem and should be a matter of further discussion. 


\section{Long-term Results}

As mentioned before, a total of 1579 cases of this series were gastrectomized by subtotal, proximal or total resection and 138 of them died within one month following operation. Although all the 1441 survivors (1579 less 138) were subjected to the follow-up study with respect to their post-operative conditions, informations were not available in 94 (6.7 per cent) of them. Accordingly, the statistics presented in this chapter are based on the remaining 1347 cases. The items of these cases are summarized in Table VII.

TabLE VII. Objectives of Follow-up Study on Gastrectomized Cases

\begin{tabular}{|c|c|c|c|}
\hline & $\begin{array}{l}\text { No. of } \\
\text { survivors }\end{array}$ & Traced cases & Trace rate \\
\hline $\begin{array}{l}\text { Subtotal gastrectomy } \\
\text { First } 10 \text { years } \\
\text { Last } 10 \text { years } \\
\text { Proximal or total gastrectomy } \\
\text { First } 10 \text { years } \\
\text { Last } 10 \text { years }\end{array}$ & $\begin{array}{rr}1160 & \\
& 477 \\
& 683 \\
281 & \\
& 45 \\
236\end{array}$ & $\begin{array}{rr}1073 & \\
& 422 \\
& 651 \\
274 & \\
& 42 \\
& 232\end{array}$ & $\begin{array}{r}92.5 \% \\
88.5 \% \\
95.3 \% \\
97.5 \% \\
93.3 \% \\
98.3 \%\end{array}$ \\
\hline $\begin{array}{l}\text { Total } \\
\text { First } 10 \text { years } \\
\text { Last } 10 \text { years }\end{array}$ & $1441 \begin{array}{r}522 \\
919\end{array}$ & $\begin{array}{r}1347 \\
464 \\
883\end{array}$ & $\begin{array}{r}93.3 \% \\
88.9 \% \\
96.1 \%\end{array}$ \\
\hline
\end{tabular}

\section{Survival rates}

Since the cases of the present series were those operated on during the period from April 1, 1941 to March 31, 1961, the post-operative period varied in these cases from two years to 22 years by March 31, 1963 on which the statistics was prepared.

Table VIII presents the survival rates of these cases in various postoperative years. The 3 year survival rate was 40.1 per cent for subtotal gastrectomy and 18.1 per cent for proximal or total gastrectomy and the 5 year survival rate 30.8 per cent for the former and 10.4 per cent for the latter. The results are also illustrated in Fig. 2. The survival curve for the total cases of stomach resection resembles that for subtotal gastrectomy cases which were the great majority of stomach resection cases. It may be seen that the curve drops rather sharply for the first five years and then slowly thereafter.

2. Recent improvements in long-term results

Walters et al. ${ }^{14}$ ) of the Mayo Clinic reported a remarkable improvement of the end-results of their stomach resections for carcinoma; the 5 year survival rate had been increased from 29.2 per cent in the years 1907 to 1916 to 34.8 per cent in the years 1940 to 1949 and the 10 year survival rate from 21.7 per cent to 26.7 per cent. Similar results were presented by Marshall and Adamson ${ }^{11)}$ from the 
TABLE VIII. Survival Rates after Stomach Resection for Stomach Cancer

\begin{tabular}{|c|c|c|c|}
\hline Years after operation & No. of cases & No. surviving & $\underset{(\%)}{\text { Survival rate }}$ \\
\hline \multicolumn{4}{|l|}{ Subtotal gastrectomy } \\
\hline 1 year & 1073 & 790 & 73.6 \\
\hline 3 years & 974 & 391 & 40.1 \\
\hline 5 years & 838 & 258 & 30.8 \\
\hline 10 years & 485 & 103 & 21.2 \\
\hline 15 years & 204 & 25 & 12.3 \\
\hline 20 years & 38 & 2 & 5.3 \\
\hline \multicolumn{4}{|l|}{ Proximal or total gastrectom } \\
\hline 1 year & 274 & 121 & 49.0 \\
\hline 3 years & 248 & 45 & 18.1 \\
\hline 5 years & 202 & 21 & 10.4 \\
\hline 10 years & 66 & 2 & 3.0 \\
\hline 15 years & 6 & $\overline{0}$ & 0 \\
\hline 20 years & 3 & 0 & 0 \\
\hline \multicolumn{4}{|l|}{ Total } \\
\hline 1 year & 1347 & 911 & 67.6 \\
\hline 3 years & 1222 & 436 & 35.7 \\
\hline 5 years & 1040 & 279 & 26.8 \\
\hline 10 years & 551 & 105 & 19.1 \\
\hline 15 years & 210 & 25 & 11.9 \\
\hline 20 years & 41 & 2 & 4.9 \\
\hline
\end{tabular}

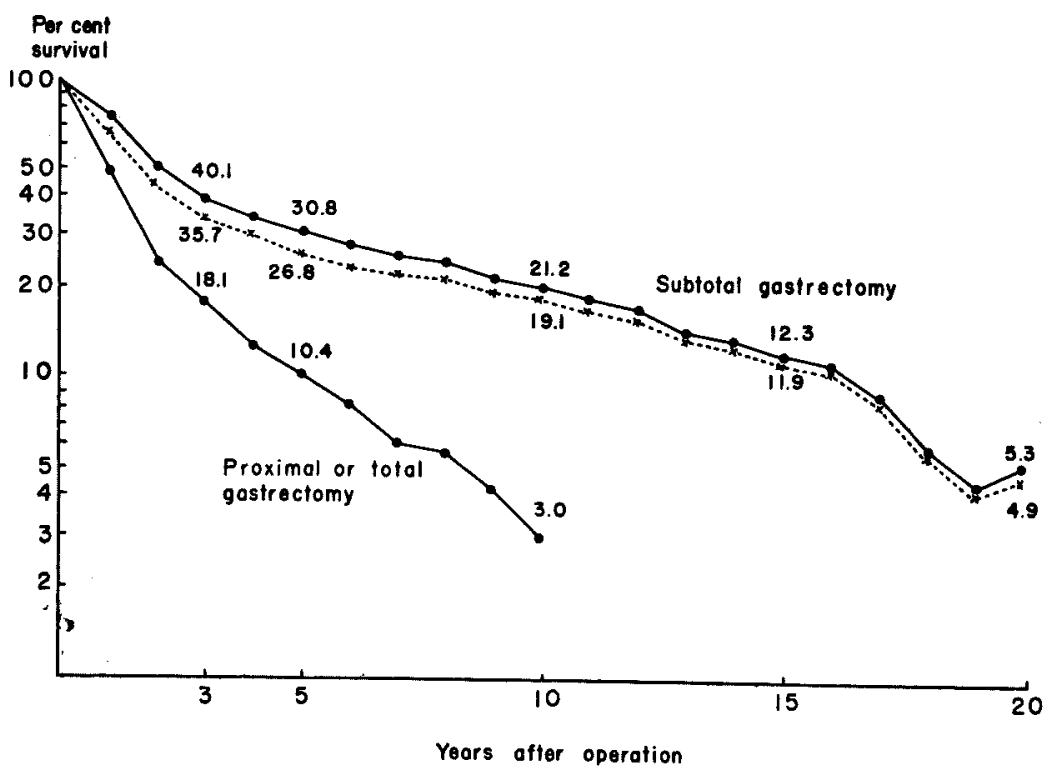

Fig. 2. Survival curves of the gastrectomized in the authors' series. The dotted curve is for the total cases of gastrectomy including subtotal, pproximal and total resections. 
Lahey Clinic. In Japan, however, few studies were concerned with an analysis of recent changes in the end-result. Based on a comparison of the end-results of different authors which appeared in literature, such as those shown in Table IX, there has been a vague idea among surgeons that the recent increase in the survival

Table IX. Long-term Results of Stomach Resection for Carcinoma, Previous Reports

\begin{tabular}{|c|c|c|c|c|c|c|c|}
\hline \multirow{2}{*}{ Authors } & \multirow{2}{*}{ Periods } & \multirow{2}{*}{$\begin{array}{l}\text { No. of } \\
\text { opera- } \\
\text { tions }\end{array}$} & \multirow{2}{*}{$\begin{array}{l}\text { No. of } \\
\text { resec- } \\
\text { tions }\end{array}$} & \multirow{2}{*}{$\begin{array}{l}\text { No. of } \\
\text { sur- } \\
\text { vivors }\end{array}$} & \multirow{2}{*}{$\begin{array}{l}\text { No. of } \\
\text { traced } \\
\text { cases }\end{array}$} & \multicolumn{2}{|c|}{ Survival rates } \\
\hline & & & & & & 3-year & 5-year \\
\hline Miyake $^{151}$ & 1904 & 1670 & 751 & 585 & 377 & $23.2 \% 6$ & $17.8 \%$ \\
\hline Tomoda \& Tomonaga ${ }^{4}$ & 1918 & 1833 & 761 & 709 & 548 & $33.8 \%$ & $22.5 \%$ \\
\hline Nakayama et al. ${ }^{61}$ & $1946-1952$ & 831 & 372 & 360 & 311 & & $23.8 \%$ \\
\hline Tsuda et al. & $1942-1955$ & 975 & 561 & 502 & $88.8 .6 *$ & $27.8 \%^{\dagger}$ & $15.7 \%$ \\
\hline Walters et al. ${ }^{17)}$ & $1907-$ & 6242 & 2772 & 2322 & $\begin{array}{l}\text { over } \\
99 \% *\end{array}$ & & $28.9 \%$ \\
\hline Ransom $^{18)}$ & 1934 & 757 & 457 & 343 & 342 & $36.46^{+}$ & $28.0 \%{ }^{\dagger}$ \\
\hline Shahon et & 1936 & 848 & 575 & 441 & 441 & & $28.6 \%$ \\
\hline Marshall \& Adamso & $1932-1954$ & 1666 & 856 & 558 & $99.6 \% *$ & & $27.2 \%$ \\
\hline Present series & $1941-1961$ & 1988 & 1579 & 1441 & 1347 & $35.7 \%$ & $26.8 \% 6$ \\
\hline
\end{tabular}

* Trace rate. $\uparrow$ The rate calculated on the basis of the number of survivors.

rate is not much significant and such an idea has stimulated some surgeons' attempts to extend the indications for total gastrectomy or to develop the so-called superradical surgery. However, inasmuch as the results of different authors are associated with different policies on surgical indications and different techniques for stomach resection, the discussion should be based on the results which were obtained in the same clinic under similar conditions.

In this connection, Table $\mathrm{X}$ shows the 3 year, 5 year and 10 year survival rates of the subtotal gastrectomy cases of this series for four consecutive 5-year-periods. It may be clearly seen that the end-results of subtotal gastrectomy have been improved a little since 1951 and quite remarkably since 1956. The authors

TABLE X. Long-term Results of Subtotal Gastrectomy for Stomach Cancer for Four Consecutive 5-Year-periods

\begin{tabular}{c|c|c|c|c}
\hline \multirow{2}{*}{ Periods } & $\begin{array}{c}\text { No. of traced } \\
\text { cases }\end{array}$ & \multicolumn{3}{|c}{ Survival rates $(\%)$} \\
\cline { 3 - 5 } & $1941-1945$ & 3 -year & 5 -year & 10-year \\
\hline $1946-1950$ & 223 & 37.2 & 26.5 & 18.3 \\
$1951-1955$ & 338 & 34.1 & 28.2 & 20.6 \\
$1956-1959^{*}$ & 281 & 37.9 & 31.1 & 24.6 \\
& 49.1 & $37.9_{+}^{+}$ &
\end{tabular}

* Cases in the year of 1960 were excluded since they were within 3 years after operation. + On the basis of 130 cases over 10 years after operation. $\ddagger$ On the basis of 145 cases over 5 years after operation. 
believe this improvement is largely due to the recent progress in early diagnosis of this disease and to some extent to the authors' attempts for better operative techniques. The 5 year survivals were as many as 37.9 per cent of those subjected to subtotal gastrectomy during the years 1956 to 1959 .

Similar results were also attained with proximal or total gastrectomy as shown in Table XI; the survival rates after these operations were significantly higher in the last 10 years than in the former. However, the results were much worse when compared to those with subtotal gastrectomy. This is quite

TABLE XI. Long-term Results of Proximal and Total Gastrectomies for Stomach Cancer for the First and the Last 10-Yearperiods

\begin{tabular}{|c|c|c|c|c|}
\hline \multirow{2}{*}{ Periods } & \multirow{2}{*}{$\begin{array}{l}\text { No. of traced } \\
\text { cases }\end{array}$} & \multicolumn{3}{|c|}{ Survival rates $(\%)$} \\
\hline & & 3-year & 5-year & 10-year \\
\hline $1941-1950$ & 42 & 11.9 & 4.8 & 0 \\
\hline $1951-1959^{*}$ & 206 & 19.4 & $11.9^{t}$ & $8.3 \ddagger$ \\
\hline
\end{tabular}

* Cf. Table $X .+$ On the basis of 160 cases over 5 years after operation.

$\ddagger$ On the basis of 24 cases over 10 years after operation.

understandable since it has been the authors' principle to perform total gastrectomy only in such cases with an extensive lesion that cannot be managed by subtotal gastrectomy. There are a number of surgeons who believe that the endresult of stomach resection would be much improved, should total gastrectomy be accepted as the basic surgery for carcinoma, even for those lesions that can be removed by subtotal gastrectomy. However, extragastric involvements of carcinoma such as peritoneal dissemination and lymph node metastasis are the main factors influencing the prognosis of gastrectomy, as will be discussed in the fourth paper, and whether total gastrectomy gives more chance for a complete removal of these extragastric extensions is questionable. Furthermore, total gastrectomy still gives higher operative mortality than subtotal gastrectomy and not uncommonly develops considerable post-operative difficulties. For these reasons the authors are of the opinion that indications for total gastrectomy should be in extensive intragastric lesions which cannot be removed without total resection of the stomach.

3. Five year survival rate based on the total cases of stomach cancer

The 5 year survival rate, or so-called 5 year cure rate, hitherto presented was calculated on the basis of patients who survived gastrectomy. However, this may not exactly represent the absolute outcome of the surgical treatment of stomach cancer since there were a considerable number of patients who were not subjected to surgery, those who were operated on but not gastrectomized and 
those who did not survive gastrectomy. The net or absolute result of surgery with considerations on all the above losses is illustrated in Fig. 3.

\begin{tabular}{|c|c|}
\hline Total cases * & $1618(100 \%)$ \\
\hline Operated cases & $1594(98.5 \%)$ \\
\hline Resected cases & $1238(76.5 \%)$ \\
\hline $\begin{array}{l}\text { Survivors of } \\
\text { gastrectomy }\end{array}$ & $1116(69.0 \%)$ \\
\hline Traced cases & $1040(64.3 \%)$ \\
\hline $\begin{array}{l}\text { Five year } 8 \\
\text { survivors }\end{array}$ & $279(17.2 \%)$ \\
\hline
\end{tabular}

Fig. 3. Analysis of the 5 year survivors of stomach cancer in relation to various kinds of mortalities. * Those admitted by the end of March, 1958.

Of a total of 2014 cases of stomach cancer treated at the authors' department during the period from April, 1941 to March, 1961, 1618 cases had been admitted by the end of March, 1958 and these were eligible to the investigation of March 31, 1963 during more than five post-operative years. When the cases who were not operated on, those who underwent simple laparotomy or palliative surgery without resection of the stomach and those without informations after gastrectomy are all assumed to have died within five years, the final five year survivals numbered 279 , or 17.2 per cent of the total. The rate is really small enough to make surgeons pessimistic but is expected to be increasing since the hospital mortality has been much lowered and the end-results of gastrectomy considerably improved in recent years, as mentioned before. Further improvements in the outcome of surgery are expected with the progress of early diagnosis, especially when the mass examination of this disease has become more popular.

\section{References}

1) Muto, M., Majima, S., Yoshida, K., Karube, K., Teshima, T. \& Yamaguchi, I., Tohoku J. Exper. Med., 1963, 81, 143.

2) Muto, M., Majima, S., Yoshida, K., Karube, K., Teshima, T. \& Yamaguchi, I., ibid., 1963, 81, 162.

3) Miyake, H., Miyagi, J. \& Taniguchi, K., Stomach Cancer (Jap.), Tokyo, 1928.

4) Tomoda, M. \& Tomonaga, Y., Rinsho Geka (Jap.), 1948, 3, 1.

5) Obara, T., Kubota, M. \& Noro, K., Iryo (Jap.), 1960, 14, Suppl. 319.

6) Nakayama, K., Yanagisawa, F., Honma, Y. \& Matsuo, S., Sogo Rinsho (Jap.), 1960, 9, 1061.

7) Hoshino, T., Geka Shinryo (Jap.), 1963, 5, 157.

8) Miwa, K., ibid., 1963, 5, 143.

9) Berkson, J., Walters, W., Gray, H.K. \& Priestley, J.T., Proc. Mayo Clin., 1952, 27, 137. 
10) Shahon, D.B., Horowith, S. \& Kelly, W.D., Surgery, 1956, 39, 204.

11) Marshall, S.F. \& Adamson, N.E., Sth. med. J., 1957, 50, 776.

12) Rapant, V., Chirurg, 1958, 29, 529.

13) Holder, E. \& Grimsehl, H., Langenbecks Arch. klin. Chir., 1960, 294, 1960.

14) Walters, W. \& Berkson, J., Ann. Surg., 1953, 137, 884.

15) Miyake, H., Grenzgebiet (Jap.), 1933, 7, 84.

16) Tsuda, S., Omori, H. \& Sano, K., Nippon Geka Gakkai Zasshi (Jáp.), 1959, 60, 347.

17) Walters, W., Gray, H.K. \& Priestley, J.T., Arch. Surg., 1943, 46, 939.

18) Ransom, H.K., Surg. Gynec. Obstet., 1953, 96, 275. 